\title{
Designing of Restaurant Information System using Rapid Application Development
}

\author{
${ }^{1}$ Wahyu Adi Prabowo, ${ }^{2}$ Citra Wiguna \\ Faculty of Informatics \\ Telkom Institute of Technology Purwokerto, Indonesia \\ 1'wahyuadi@ittelkom-pwt.ac.id, ${ }^{2}$ citra@ittelkom-pwt.ac.id
}

\begin{abstract}
Indonesia is one of the largest culinary attractions in Southeast Asia. The culinary diversity in Indonesia encourages stakeholders to create restaurant businesses with effective and efficient business processes. One of the efforts to make the restaurant business process effective and efficient is to build a restaurant management information system. By using a system, business actors will be able to control and evaluate their business with appropriate reports. For this reason, the purpose of this study is to build a restaurant management information system using the RAD (Rapid Application Development) method, because building this application requires a systematic, structured, and object-oriented process. The RAD method emphasizes a high quality systems, fast development and delivery and low costs development process [1] so that this process requires a serious role from business actors to build a restaurant management information system. The results of this system design can make it easier for business actors to control the business process from the customer to the kitchen so that the food and beverage ordering process will be served quickly. The GUI restaurant management information system is made interactively so that customers and business actors can easily understand the system. The test results of this system use black-box testing, with the conclusion that the system is successful to run.
\end{abstract}

Keywords - Information System, Rapid Application Development, Blackbox Testing.

\section{INTRODUCTION}

The business process activities of the restaurant business are food and beverage business activities that can last a long time and are a necessity for everyone [2]. The increase in the food and beverage business process activities in Figure 1, quoted from aseanbriefing.com (2019) states that Indonesia is a country that has the largest foodservice in Southeast Asia. In Indonesia, the driving force for the food and beverage business is in full-service restaurants, fast food, and suburban food stalls [3].

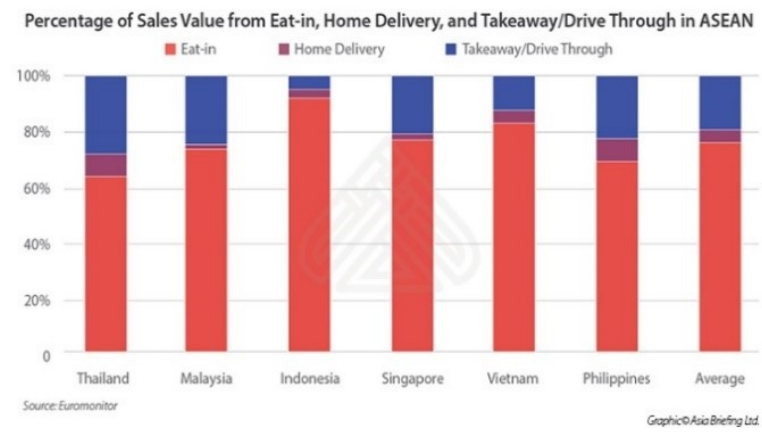

Figure 1. Percentage of service value and volume of Southeast Asia food production

For this reason, food and beverage business actors, both small and large, must improve their internal business systems for the progress of their companies [4]. One of the efforts to improve the internal system is to build a well-coordinated information system. A common problem that occurs in restaurants is the inaccurate synchronization of reporting on the profits of business activities and restaurant business operations. So that business actors will difficult to measure and difficult to book their business performance [5]. For that, we need a system that can control and evaluate the business with accurate reporting from upstream to 
downstream of the restaurant business process.

Several researchers have made a solution to this problem, for example, a mobile-based management system in a local server network. In this study, there is still a constraint that chefs must be able to refresh data to the server every time there is an order so that the data is not automated into the ordering service system [6]. Another study is the problem with data ordered by customers and which are presented differently so that customers feel disappointed because they feel that the menu is not served properly [7].

To produce quality information, an information system that has certain characteristics is needed [8]. System characteristics, namely: system components, system boundaries, subsystems, external environment, system liaison, system input, system output, system processing, and system objectives [9]. Information system design can be implemented in various fields such as finance, inventory, education, to human resources in companies. Using the RAD method can combine special techniques and computer tools to accelerate the analysis, design, and implementation stages. The RAD method also functions as a method of evaluation and feedback from users [10]. This method is based on intensive meetings with all important stakeholders (for example, developers and users), where after all the stakeholders come together they will produce specifications according to business needs or processes [11].

Based on the background exposure, the researcher's concentration will be to create an integrated web-based restaurant management information system so that the report data on restaurant business operations will be recorded properly so that it can reduce data mismatch in the restaurant business processes. Therefore, the restaurant business process can apply a web-based information system [12].

\section{METHOD}

The method used to implement the restaurant management information system is the researcher using the RAD (Rapid Application Development) method. This method is used because the method of implementing information systems can suit the needs of the users [13]. The cycle in this RAD stage can be seen in Figure 2.

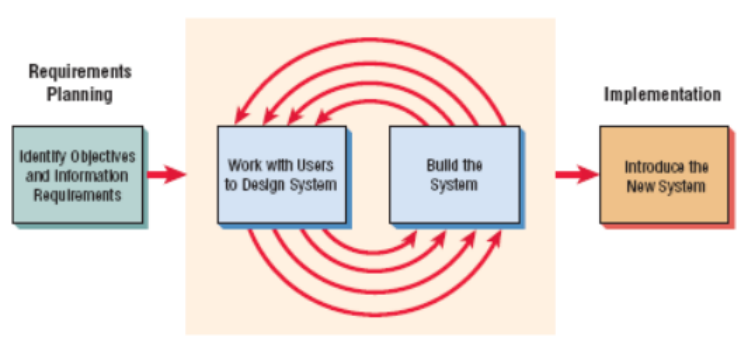

Figure 2. RAD Stages [14]

In making information systems under user needs, the process must be systematic, structured, and object-oriented [15]. The 3 completion phases for the restaurant management information system based on the RAD method can be explained as follows [16]:

1. Requirements planning

For this phase, the researcher met with stakeholders to find out the wants and identify the system objectives and requirements for the information system to be built.

\section{RAD design workshop}

In this phase, the researcher builds and implements a system that can be described as a workshop. Researchers build information systems and directly visualize their designs and business processes to stakeholders. During the workshop process, stakeholders can immediately respond to the information system built and can correct modules that are not by the wishes of business stakeholders.

\section{Implementation}

In this phase, researchers and stakeholders discuss with each other to create a restaurant management information system during the workshop. Not only the system but also designing appropriate business processes for stakeholders before they are used in their place of business. After approval from all 
aspects, the information system is tested and introduced to the organization.

\section{RESULTS AND DISCUSSION}

The restaurant management information system is an integrated system in each restaurant business operation line. This system can make it easier for stakeholders to control every report on the restaurant business operations. This restaurant management information system offers a complete web-based food ordering system with POS, cashier, kitchen, tables that can be adjusted to meet the requirements of restaurant and cafeteria businesses to increase inventory positions, increase profits, and better customer service by optimizing workforce needs and reduce operating costs. The system built is comprehensive and is ready to be used for small, medium to large restaurants. This system is built so that stakeholders can easily use the application and build it simply according to stakeholder needs. This system is built to suit all types of restaurants and restaurants with user-level adjustments. This restaurant information system uses a web-based two-tier architecture that is safe to use. The two-tier model is a client/server configuration that is divided into 2 entities, namely the client and server application [17] which can be seen in Figure 3.

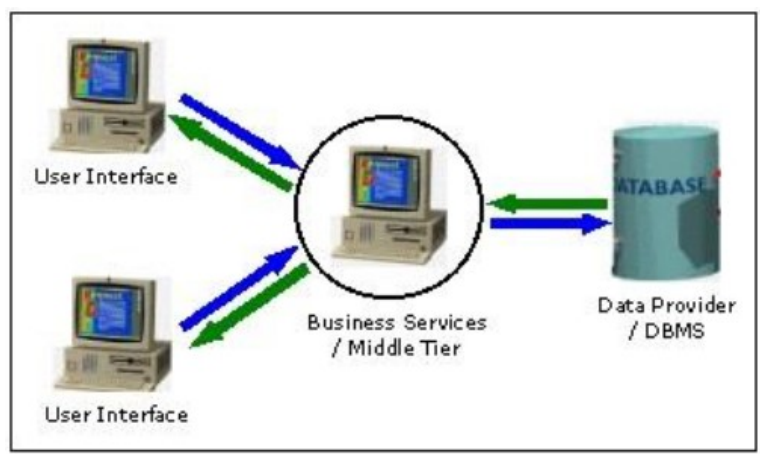

Figure 3. Model Two Tier [17]

This restaurant management information system device runs on the Windows 7 platform or higher that has Mozzila Firefox or Google Chrome connected online to the internet. The programming language for this system uses PHP (Hypertext Preprocessor), CSS (Cascading Style Sheet), and Java Script. This restaurant management information system is a software that provides information data regarding food and beverage menu data along with prices presented in tabular form. This system interacts with the system through a GUI (Graphical Customer Interface) interface. This system application gets menu data from the admin. An admin who performs menu data input according to the available menu with the help of systems on the web. The menu data is then processed and stored in the database server. Processing the data will produce information that will be displayed in the menu table.

Use case diagrams in this system are used by actor roles to gain access to this system. Login is based on a unique id which is the character of the customer name and password. The design of this use case can be seen in Figure 4.

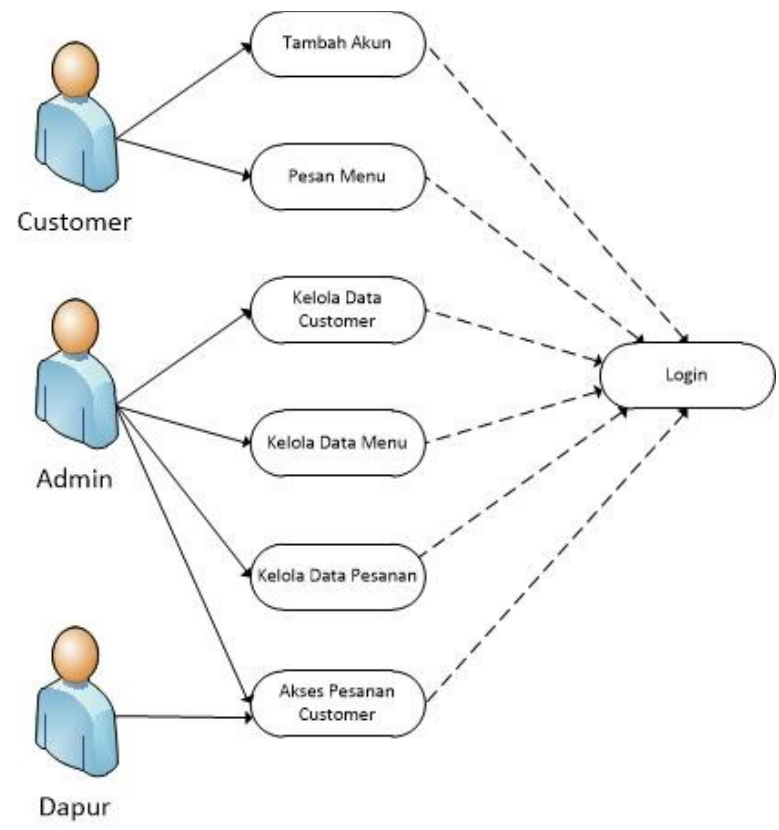

Figure 4. Use Case Diagram

In Figure 5, the interface on this system is the main web display. Apart from containing information about the interface, this system is also able to log into the system which is only for the customer. Customers must enter their username and password correctly in the textbox provided. When the login button is 
pressed, the system will check the entered username and password, with the username and password that have been stored in the database. If the username and password data is correct or matched, the user will enter the system, otherwise, if the username and password are incorrect or not matched, a warning message will be given.

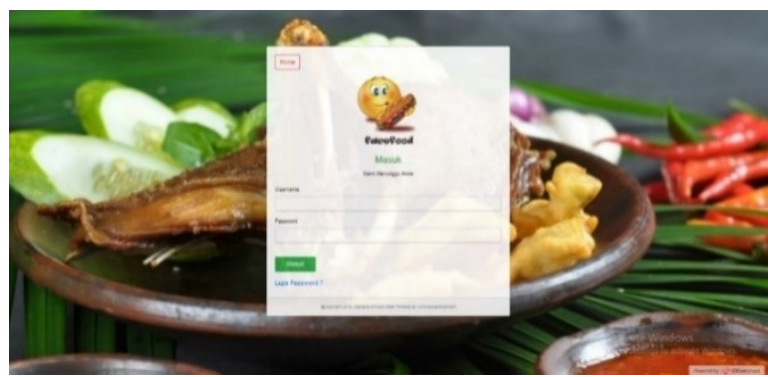

Figure 5. Home Interface (Login)

In Figure 6, this password change interface is used to change the user's password. The full name textbox cannot be changed if you want to change it must contact the admin. Users can change their email, username, and password in the provided textbox and then click the update button. Then the system will change the data in the database.

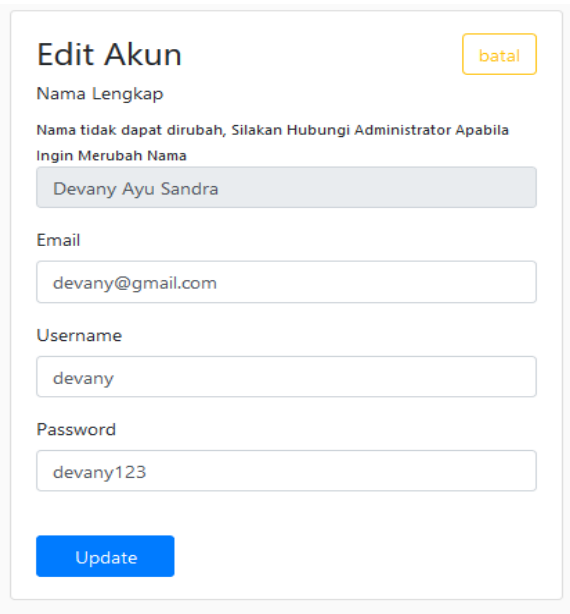

Figure 6. Change Password Interface

Figure 7 This food order menu interface is a page for ordering food. This interface provides info about the order menu. This menu consists of managing order data, in the form of add, change, and delete. From this menu, customers can choose the food and drinks they want to order then, this order data will be sent directly to the kitchen actor role menu so that the orders that have been entered are processed immediately to be sent to the customer.

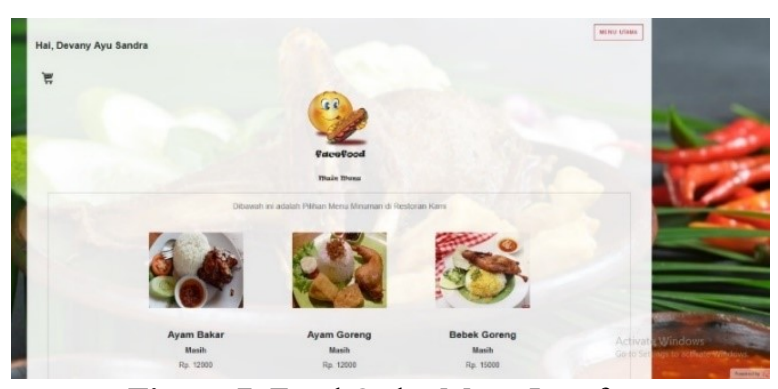

Figure 7. Food Order Menu Interface

Figure 8 This menu data interface is a special page for Admin. This interface provides info and input regarding the available menu lists. Menu Data Menu consists of add, change, and delete menus.

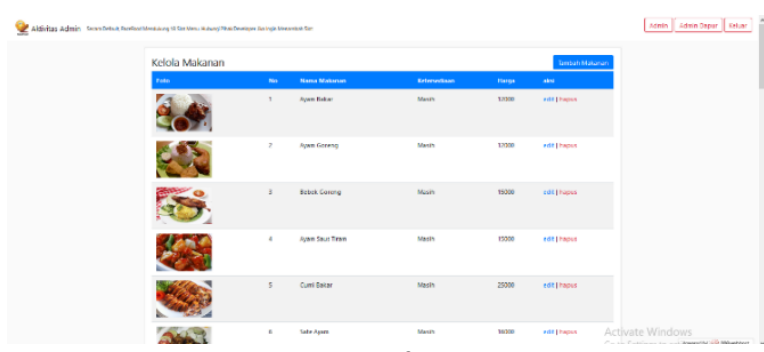

Figure 8. Interface Data Menu

In figure 9, the menu interface for order data access is a special page for kitchen admins. This interface provides order info that must be delivered to the customer. This menu consists of Access Order Data, and Delete Order Data.

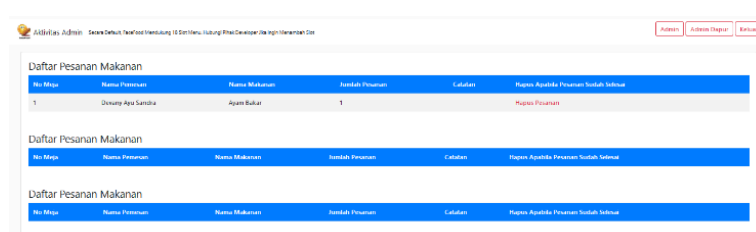

Figure 9. Interface of Order Data Access Menu

Testing for the restaurant management information system uses black-box testing to determine the capabilities of the program that has been designed to suit stakeholder desires. This test is carried out so that 
researchers can be given input on the ability of the program whether it is under the wishes of the stakeholders by the desired functional requirements [18]. The results of this test can be seen in table 1 .

Table 1. Description of Test Results

\begin{tabular}{|c|c|c|c|c|c|c|}
\hline Description & $\begin{array}{c}\text { Testing } \\
\text { procedure }\end{array}$ & Input & Output & $\begin{array}{c}\text { Outcome } \\
\text { evaluation } \\
\text { criteria }\end{array}$ & Results & Conclusion \\
\hline $\begin{array}{l}\text { Sign in } \\
\text { Testing }\end{array}$ & $\begin{array}{l}\text { Enter } \\
\text { username and } \\
\text { password to } \\
\text { enter account. }\end{array}$ & $\begin{array}{l}\text { Username } \\
\text { and } \\
\text { Password }\end{array}$ & $\begin{array}{l}\text { The system } \\
\text { does not return } \\
\text { to the sign in } \\
\text { page }\end{array}$ & $\begin{array}{l}\text { Customer data } \\
\text { fields that are } \\
\text { not filled in } \\
\text { there will be an } \\
\text { order "All fields } \\
\text { must be filled } \\
\text { in" }\end{array}$ & success & accepted \\
\hline $\begin{array}{l}\text { Test Change } \\
\text { Password \& } \\
\text { Forgot } \\
\text { Password }\end{array}$ & $\begin{array}{l}\text { Enter the new } \\
\text { username \& } \\
\text { password }\end{array}$ & $\begin{array}{l}\text { New } \\
\text { Username \& } \\
\text { Password }\end{array}$ & $\begin{array}{l}\text { The system } \\
\text { does not return } \\
\text { to the sign in } \\
\text { page }\end{array}$ & $\begin{array}{l}\text { The system will } \\
\text { generate a } \\
\text { password when } \\
\text { the customer } \\
\text { forgets the } \\
\text { password }\end{array}$ & success & accepted \\
\hline $\begin{array}{l}\text { Testing } \\
\text { Menu Data } \\
\text { Ordering }\end{array}$ & $\begin{array}{l}\text { The system } \\
\text { will display } \\
\text { the main page }\end{array}$ & $\begin{array}{l}\text { Menu Food, } \\
\text { Beverages, } \\
\text { and Dessert } \\
\text { Button. } \\
\text { Then } \\
\text { Message on } \\
\text { each Menu } \\
\text { Button }\end{array}$ & $\begin{array}{l}\text { The order goes } \\
\text { smoothly and } \\
\text { goes to the } \\
\text { administrator }\end{array}$ & $\begin{array}{l}\text { Customer order } \\
\text { data fields that } \\
\text { are not filled in } \\
\text { there will be an } \\
\text { order "All fields } \\
\text { must be filled } \\
\text { in" }\end{array}$ & success & accepted \\
\hline
\end{tabular}

\section{CONCLUSION}

This restaurant management information system is built using a two-tier architectural model because the database used is separated from the client so that the database can be accessed by anyone with an interest in the restaurant's business process system. This architectural model also makes it easier for users to get data and then the data is directly distributed back to the user. A reliable interface and supported by a GUI (Graphic User Interface) that is easy to use, built using the PHP programming language (Hypertext Preprocessor), CSS (Cascading Style Sheet), and Java Script. Usecase diagrams are designed using 3 main actor roles, namely customer, admin, and kitchen to produce effective and efficient reporting data on ongoing business processes.

For the experiment, the description of the test results obtained in the implementation of the restaurant management information system design using the RAD (Rapid Application Development) method is under the quality and needs of the stakeholders. The importance of using the RAD method, in terms of work in making the restaurant management information system, the implementation time will be faster and have the quality required by stakeholders. In each module work refers to the RAD method so that it is more effective and efficient in its processing.

Because by using this RAD method, researchers and stakeholders always interact with the making of the system so that it can meet user needs. The completion of the modules carried out refers to the needs desired by the stakeholder so that it makes it easier to work on them. With this restaurant management information system design, operational reports in business processes will be well controlled because every transaction will be directly entered into the system 
database. For stakeholders, it will be easy to control every document needed for the progress of their business ventures.

\section{REFERENCES}

[1] [1]C. Jones, "49 Rapid Application Development (RAD)," in Software Methodologies A Quantitative Guide, 2017, pp. 381-384.

[2] D. Amrullah, "Strategi Pengembangan Bisnis Restoran Makassar Berbahan Baku Hasil Ternak dalam Mendukung Penyediaan Makanan Sehat," Manaj. IKM, vol. 11, no. 1, pp. 1-9, 2016, [Online]. Available: http://journal.ipb.ac.id/index.php/jurnal $\mathrm{mpi} /$.

[3] J. Herianto, Michael., \& Gunawan, "Identifikasi karakteristik pada industri restoran di Surabaya," J. Sains dan Seni ITS, vol. 8, no. 2, 2019.

[4] T. Soewanda, P. M. Bisnis, P. S. Manajemen, U. K. Petra, and J. Siwalankerto, "Rumah Makan Nasi Bebek Pak Janggut Di Surabaya," vol. 3, no. 1, 2015.

[5] N. N. Wahid, "Pengaruh kemampuan menyusun laporan keuangan dan motivasi terhadap kinerja ukm di kota tasikmalaya," Ris. Akutansi dan Bisnis, vol. 12, no. 1, pp. 53-68, 2017, [Online]. Available: http://jurnal.unsil.ac.id/index.php/jak/ar ticle/view/295/207.

[6] M. R. Perkasa, R. Kridalukmana, and E. D. Widianto, "Perancangan Sistem Manajemen Restoran dengan Aplikasi Pemesanan Restoran Berbasis Mobile dalam Jaringan Lokal,” J. Teknol. dan Sist. Komput., vol. 4, no. 2, p. 289, 2016 , doi: 10.14710/jtsiskom.4.2.2016.289-294.

[7] Herfin, K. Wijana, and E. Kurniawan, "Sistem Informasi Manajemen Rumah Makan Berbasis Mobile (Studi Kasus Co-Cowmilk)," J. EKSIS, vol. 5, no. 1, pp. 30-34, 2012.

[8] Tundung Subali PatmaMohammad MaskanAlifiulahtin Utaminingsih,
"Sistem Informasi Manajemen Guna Mendukung Keputusan," in Sistem Informasi Manajemen Guna Mendukung Keputusan, 1st ed., Indonesia: Polinema Press, 2018, p. 60.

[9] R. I. Elisabet Yunaeti Anggraeni, "Pengantar Sistem Informasi," in Pengantar Sistem Informasi, 1st ed., Indonesia: ANDI Yogyakarta, 2017, p. 148.

[10] A. Dennis, B. H. Wixom, and R. M. Roth, System Analysis and Design 5th Edition. 2012.

[11] S. D. B. John W. Satzinger, Robert B. Jackson, "Systems Analysis and Design in a Changing World," in Systems Analysis and Design in a Changing World, New York: Cengage Learning, 2016, p. 512.

[12] T. Handayani, I. Gunawan, and R. Taufiq, "Rancang Bangun Sistem Informasi Pemesanan Menu Makanan Berbasis Web (Studi Kasus: Restoran Bukit Randu Bandara)," J. SITECH Sist. Inf. dan Teknol., vol. 3, no. 1, pp. 21-28, 2020, doi: 10.24176/sitech.v3i1.4837.

[13] R. Saptono and R. Anggrainingsih, "Development of Software Size Estimation Application using Function Point Analysis (FPA) Approach with Rapid Application Development (RAD)," ITSMART J. Teknol. dan Inf., vol. 5, no. 2, pp. 96-103, 2017, [Online]. Available: https://jurnal.uns.ac.id/itsmart/article/vi ew/1988.

[14] A. Ananta, "Sistem Informasi Inventaris Laboratorium Komputer Menggunakan Model Rapid Application Development Pada STMIK Lamappapoleonro Soppeng," J. Ilm. Sist. Inf. dan Tek. ..., vol. 3, no. April, pp. 20-28, 2020, [Online]. Available: https://ojs.stmik.ypls.ac.id/index.php/ji sti/article/view/48.

[15] F. Fatoni and D. Irawan, "Implementasi Metode Extreme Programming dalam Pengembangan Sistem Informasi Izin Produk Makanan,” J. Sisfokom (Sistem 
Inf. dan Komputer), vol. 8, no. 2, p. 159, 2019, doi: 10.32736/sisfokom.v8i2.679.

[16] KENNETH E. KENDALL and JULIE E. KENDALL, Analisis Y Diseño De Sistemas. 2011.

[17] S. Wahyu Pujiyono, M. Idham Ananta Timur, "Perbandingan Model Two-Tier dengan Three-Tier dalam Arsitektur Client/Server untuk Mengolah Perintah Query pada Aplikasi Database," pp. 17-25, 2004.

[18] R. R. Latief, A. Achmad, and S. Sahibu, "Aplikasi Pencarian Ustadz Untuk Wilayah Kota Makasar Menggunakan Algoritma Floyd Warshall Dan Haversine Formula Berbasis Android," Sebatik, pp. 337342, 2014. 